\title{
MODEL GAYA HIDUP NAZIR SEBAGAI REFLEKSI GAYA HIDUP HEDON PENGKOTBAH PADA ZAMAN MILENIAL
}

\author{
T. Haryono ${ }^{1}$ dan Daniel Fajar Panuntun ${ }^{2}$ \\ ${ }^{1}$ Sekolah Tinggi Teologi Gamaliel, ${ }^{2}$ Sekolah Tinggi Agama Kristen Negeri Toraja \\ Email: ${ }^{1}$ tharyono@ stt-gamaliel.ac.id, ${ }^{2}$ daniel_fp@ stakntoraja.ac.id
}

\begin{abstract}
T. Haryono \& Daniel Fajar Panuntun. In this era, there were a rapidly development specifically in the field of technology and media. The global idea or opini was influenced by media. This matter effected into the habbit of the global lifestyle. The emotional benefit from the life style more important than the functional benefit and it happened in the indonesian consumers. This life style was affected into preacher that specifically affected a hedonic lifestyle. The preacher's life style in in the middle millenial era had to reviewed again so the lifestyle of the preacher can be made good, right, and proper example by all the believer. The aim of this research was to knew the lifestyle of the preacher in the millenial era. The metode of this research use a qualitative with bible study, literatur study and interview then it been analysed with interatif method. The result of this research is captured a lifestyle of nazir as a reflection of the life style for the the preacher in the millenial era. The model is described into principle, steps, and the motivation of the preacher lifestyle..
\end{abstract}

Key words : Lifestyle Model, millenial, preacher

\begin{abstract}
ABSTRAK: T. Haryono \& Daniel Fajar Panuntun. Pada masa kini terjadi perkembangan yang sangat pesat di berbagai bidang terkhusus pada bidang teknologi dan media. Sumber ide dan opini secara global dipengaruhi oleh media. Hal ini berimbas kepada masalah gaya hidup (life style). Manfaat emosional dari gaya hidup yang lebih utama daripada manfaat fungsional terjadi pada kalangan konsumen masyarakat Indonesia. Gaya hidup ini juga berdampak pada kehidupan pengkotbah dimana terpengaruh pada gaya hidup hedon. Gaya hidup pengkotbah pada masa kini di tengah zaman milenial perlu di kaji ulang sehingga kehidupan pengkotbah dapat dijadikan teladan yang baik, benar, dan tepat oleh seluruh orang percaya. Tujuan dari penelitian ini adalah untuk mengetahui gaya hidup pengkotbah pada zaman milenal. Metode penelitian yang digunakan dengan pendekatan kualitatif melalui studi Alkitab, studi pustaka, wawancara yang kemudian dianalisis dengan metode interaktif. Melalui penelitian ini didapatkan model gaya hidup nazir sebagai refleksi gaya hidup hedon pengkotbah pada zaman milenial. Model gaya hidup tersebut dijelaskan berdasarkan prinsipnya, langkah-langkah gaya hidup, dan motivasi gaya hidup tersebut.
\end{abstract}

Kata kunci : Model gaya hidup, milenial, pengkotbah

\section{PENDAHULUAN}

Pada abad ke-21 ini, media baik media cetak maupun media elektronik mengalami perkembangan yang sangat pesat. Dalam perkembangan teknologi dan masyarakat yang begitu maju, media merupakan salah satu kebutuhan manusia untuk mendapatkan informasi (Goenawan, 2008, p. 183). Dampak global dari perkembangan pesat ini mulai munculnya variasi gaya hidup (life style). Banyak informasi yang bisa didapatkan dari media komunikasi, salah satunya adalah televisi. Kebiasaan melihat telivisi ini secara mudah banyak mempengaruhi gaya hidup masyarakat luas. Iklan-iklan yang berpengaruh terhadap cara berpikir dan bertindak masyarakat luas (Gunawan, 2015, p. 1).

Sumber ide dan opini secara global dipengaruhi oleh media. Hal ini berimbas kepada masalah gaya hidup. Life style segmentation adalah segmentasi ditinjau dari bagaimana konsumen berpikir, berinteraksi, menjalani hidup, yang ternyata dapat mempengaruhi perilaku pembelian (Wright, 2006, p. 392). Consumer life style adalah pola perilaku yang merefleksikan bagaimana seseorang ataupun keluarga memilih untuk menghabiskan waktu dan uang mereka (Wright, 2006, p. 397). Manfaat emosional dan gaya hidup (emotional\& life style benefits) lebih 
diutamakan daripada manfaat fungsional (functional benefit) untuk konsumen menengah ke atas.

Manfaat emosional dan gaya hidup yang lebih utama daripada manfaat fungsional terjadi pada kalangan konsumen masyarakat Indonesia (Annisa, 2014, p. 521). Pengaruh gaya hidup ini mempengaruhi masyarakat Indonesia yang cenderung konsumtif dan hedonis. Beberapa penelitian yang berkaitan mengenai gaya hidup tersebut diantaranya adalah penelitian Bernatta (2017, p. 1) gaya hidup hedonis di kalangan remaja, kemudian penelitian Annisa (2014, p. 521) tentang alasan gaya hidup konsumen dalam mengonsumsi kebaya sebagai barang mewah, lalu penelitian yang dilakukan oleh Solihin (2015, p. 41) tentang terpaan iklan mendorong gaya hidup konsumtif masyarakat urban, dan Gunawan (2015, p. 1) yang meneliti tentang reprenstasi gaya hidup mewah dalam iklan televisi es krim magnum versi, "Magnum Classic". Berbagai penelitian tersebut menunjukkan adanya gaya hidup masa sekarang yang memiliki kecenderungan hedonis dan konsumtif.

Gereja perlu terus menerus menyuarakan kritik profetisnya tanpa pandang bulu terhadap berbagai penyalah gunaaan kekuasaan, terjadinya ketidakadilan, terampasnya hak-hak masyarakat, dan terhadap sistem yang telah menindas serta memiskinkan manusia. Spiritualitas dan religiusitas jemaat juga harus sampai kepada sebuah kesalehan sosial, dimana energi spiritual yang dimiliki jemaat mampu untuk mendorong kepeduluannya akan berbagai persoalan kehidupan masayarakat (Nugroho, 2019, p. 100). Gereja harus dapat memenuhi panggilan tersebut pada konteks dunia ini oleh karena itu peran seorang pengkotbah sangat penting sebagai role model gaya hidup seluruh jemaat atau anggota persekutuan yang dilayani.

Hal yang memprihatinkan adalah sebagian gereja dan pemimpinnya belum siap untuk menghadapi perubahan besar ini padahal umat sudah memasuki dunia digital ini (Ronda, 2019, p. 2).Karena hal tersebut, pengaruh gaya hidup ini juga berdampak pada kehidupan para pengkotbah. Tugas dan pekerjaan seorang hamba Tuhan atau rohaniwan dipan- dang sebagai sebuah profesi. Kondisi ini terjadi, karena kurangnya pemahaman orang percaya mengenai kata "profesi" yang sebenarnya (Tandhiy, 2017, p. 75). Kehidupan pengkotbah terkena imbas gaya hidup masa sekarang oleh karena pandangan dan gaya hidup masyarakat umum pada masa kini. Pandangan yang salah dari seorang pengkotbah juga berdampak pada gaya hidupnya. Pandangan keliru yang berkembang di kalangan orang percaya adalah memandang profesi cenderung berbau sekuler dan mementingkan profit daripada pelayanan dan pengabdian (Nurdin, 2005, p. 13).

Perasaan yang diberikan oleh Allah kepada manusia sebagai cerminan atau citra diri-Nya adalah perasaan murni, nyaman, penuh kasih sayang, perasaan sukacita dan damai sejahtera. Kejatuhan manusia dalam dosa membuat perasaannya menjadi tidak seperti semula, perasaanya menjadi rusak. Namun ketika seseorang percaya kepada Kristus maka perasaanya pun akan diubahkan sehingga dapat kembali seperti semula, penuh kasih, dan sukacita (Sitanggang, 2019, p. 55). Secara dinamis gaya hidup orang yang percaya Yesus akan diubahkan menuju hal yang lebih baik. Seperti halnya kecenderungan orang yang tertutup atau susah untuk mempercayakan masalahnya karena pengaruh globalisasi, menurut Haryono (2019, p. 12) dapat diubahkan melalui pemuridan kontekstual. Permasalahannya adalah gaya hidup yang salah semakin banyak penggodanya pada zaman milenial ini. Penelitian mengenai gaya hidup pada masa kini sangat penting untuk dilakukan. Gaya para pengkotbah yang melayani pada masa kini di tengah zaman milenial perlu dikaji ulang sehingga kehidupan pengkotbah dapat dijadikan teladan yang baik, benar, dan tepat oleh seluruh orang percaya. Refleksi atas gaya hidup para pengkotbah dibandingkan dengan pelayan Tuhan pada masa Alkitab yaitu para Nazi Allah yang gaya hidupnya sudah jelas memiliki peraturan yang jelas. Refleksi atas gaya hidup seorang nazir ini dapat diratik relevansinya untuk gaya hidup para pengkotbah pada masa kini yang keduanya memiliki persamaan dalam pekerjaan pelayanan Tuhan. 
Berdasarkan latar belakang tersebut dapat ditarik suatu rumusan masalah penelitian yaitu: $\mathrm{Ba}-$ gaimana gaya hidup nazir sebagai refleksi gaya hidup hedon pengkotbah pada zaman milenial? Tujuan dari Penelitian ini adalah untuk mengetahui gaya hidup nazir sebagai refleksi gaya hidup hedon pengkotbah pada zaman milenial. Manfaat yang diperoleh dari hasil penelitian ini adalah: pertama, memberikan sebuah model gaya hidup yang dapat diterapkan oleh para pengkotbah sehingga pelayanannya semakin berbuah; kedua, dapat memberikan padangan pada setiap orang percaya untuk mengerti tentang kehidupan Pengkotbah dan pergumulan yang dihadapinya sehingga dapat menempatkan sudut pandang yang tepat ketika melihat gaya hidup seorang pengkotbah; ketiga, mendorong Jemaat untuk bertumbuh dengan gaya hidup yang benar di tengah tuntutan zaman milenial dengan meneladani kehidupan dari para pengkotbah.

\section{METODE}

Metode penelitian pada penelitian ini adalah menggunakan pendekatan kualitatif (Lumintang, 2016, p. 99). Pendekatan kualitatif dilakukan dengan urutan penyajian data deskriptif yang terdiri atas: pertama: Gaya hidup Nazir melalui pendekatan studi teks Alkitab. Kedua, pendekatan deskiptif dari para ahli mengenai gaya hidup para pengkotbah. Ketiga, deskripsikecendrungan gaya hidup para pengkobah pada masa kini. Keempat, deskripsi data dari pertanyaan wawancara yang diajukan di lapangan. Keli$m a$, proses analisis dari data-data tersebut. Analisis yang digunakan dalam penelitian ini adalah dengan menggunakan metode interaktif yaitu pengumpulan data, penyajian data, reduksi data dan penarikan kesimpulan (Miles, 1984, 23). Proses reduksi data dilakukan dengan tabulasi tesis-antitesis untuk menghasilkan sintesis gaya hidup. Proses selanjutnya adalah penarikan kesimpulan dari proses sintesis tersebut.

Pengumpulan data dilakukan dengan menggunakan sumber literatur pustaka, studi teks Alkitab dan penelitian ini juga melibatkan penelitian lapangan dengan wawancara (Sugiyono, 2015, p. 477-478) yang dibatasi pada beberapa Pengkotbah (pendeta, pelayan full timer, tim pelayan) yang ada di Surakarta. Wawancara dilakukan dengan mengirimkan instrumen pertanyaan dan para responden diminta data dengan penjelasan-penjasan. Instrumen pertanyaan dapat berupa pertanyaan yang terbuka dan peneliti dapat menambah pertanyaan sehingga didapatkan data yang jelas mengenai kecenderungan gaya hidup pengkotbah pada masa kini. Instrumen pertanyaan sebagai pendukung untuk memperkuat datadata deskritif yang disusun adalah sebagai berikut: pertama, Bagaimana kecendrungan gaya hidup global masa kini? (Gaya hidup sesuai perkembangan Zaman). Kedua, Apakah ada gaya hidup pengkotbah pada masa kini yang tidak tepat? Mohon berikan penjelasan secara deskritif! Ketiga, Mengapa pengkotbah memiliki gaya hidup yang tidak tepat pada masa kini? Mohon berikan faktor-faktor yang mempengaruhinya! Keempat, menurut anda bagaimanakah gaya hidup pengkotbah yang paling tepat pada pelayanan masa kini (zaman milenial)?

Definisi istilah yang digunakan pada penelitian ini adalah Pengkotbah pada penelitian ini didefinisikan yaitu hamba Tuhan yang melayani dalam pelayanan khotbah atau homiletik. Pengkobah ini bukan hanya mengacu pada pendeta saja namun juga mereka yang berkotbah baik kepada jemaat, anggota persekutuan dan audience pada umumnya. Pengkotbah ini di klasifikasikan yaitu pendeta yang melayani khotbah, full timer pelayan yang juga dapat melayani khotbah-khotbah baik di gereja maupun di persekutuan-persekutuan dan tim pelayan yang tidak full timer tapi mendedikasikan diri untuk pelayanan salah satunya adalah dengan berkhotbah pada audience umum baik seperti acara penghiburan kematian, acara ucap syukur, dan lainnya.

\section{HASIL DAN PEMBAHASAN}

Hasil dari penelitian ini merupakan rujukanrujukan pustaka yang dikumpulkan berdasarkan metode pengumpulan data yang telah dilakukan yang kemudian di bagi ke dalam 4 sub bab yang memberikan deskripsi mengenai pembentukan model 
yang akan di bahas. Pembahasan berisikan hasil 2 sub bab analisis dan 1 sub bab penyusunan model.

\section{Gaya hidup Nazir Allah menurut Bilangan 6:1-4.}

NAZIR, Ibrani נזיר - נזר - NAZIR, dari kata $N A Z A R$, yang artinya menga-singkan, menahbiskan, berpantang'; bandi-ngkan kata ini dengan NAZER, artinya adalah 'mahkota', 'mahkota Allah', kadang-kadang juga disamakan dengan rambut yang tidak dicukur yang diterapkan pada seorang Nazir. Di Israel, seorang nazir adalah yang mengasingkan diri dari orang lain dengan mengkhususkan dirinya bagi YHWH dengan suatu NAZAR khusus (Perpustakaan online, 2019).

Nama Nazir sendiri tidak bisa disamakan dengan Nazarene yaitu penduduk dari kota Nazaret. Seorang Nazir akan membuat sumpah yang dinyatakan secara terbuka dan memberikan diri kepada Tuhan pada waktu tertentu untuk melakukan pelayanan tertentu (Fleming, 2005, p. 66). Seorang nazir memiliki dorongan kuat menuju kehidupan suci dan meninggalkan pekerjaan duniawi tertentu dan kesenangannya dalam jangka waktu tertentu (Gray, 199, p. 410). Berdasarkan hal tersebut kualifikasi seorang nazir adalah dia yang memisahkan diri untuk melakukan sumpah tertentu, hidup dalam kesucian dengan meninggalkan pekerjaan dan kesenangan duniawi pada periode waktu tertentu.

Salah satu gaya hidup seorang Nazir tidak diperbolehkan meminum anggur, bahkan makan dari segala sesuatu yang berasal dari pohon anggur dari bijinya sampai pucuk rantingnya (Bil. 6:3-4). Pembatasan diri yang dilakukan adalah untuk membatasi diri dalam minum anggur. Alasan pembatasan diri ini jelas karena penggunaan anggur cenderung mengobarkan gairah, memabukan otak dan menciptakan selera untuk kesenangan mewah. Kemewahan adalah simbol yang harus dicabut untuk menyatakan kemurnian yang dianutnya. Salah satu dampaknya adalah supaya orang lain meniru teladan salehnya (Jamieson, 2009, 243). Mereka yang memisahkan diri dengan Tuhan, tidak boleh memuaskan keinginan tubuhnya tetapi harus bisa menakhlukannya. Hal ini juga sebagai peringatan untuk semua orang Kristen yang cinta anggur dan minum-minum. Apabila kecintaan tersebut menguasai seseorang maka ia menjadi mangsa yang sangat mudah bagi setan. Orang-orang yang bernazar (nazir) tidak boleh makan apapun yang berasal dari pokok anggur, ini mungkin mengajarkan cara terbaik untuk menghindari dosa dan semua yang berbatasan dengannya sehingga dapat menuntunnya dan tidak menjadi pencobaan bagi manusia (Henry, 2005, p. 185). Berdasarkan hal tersebut kesalehan dari seorang Nazir sangat dijaga dan dalam kehidupannya dia harus bisa menghindari setiap perbuatan dosa sehingga memiliki disiplin dan peraturan hidup yang sangat ketat.

Motivasi seorang nazir adalah sumpah menurut kehendak mereka sendiri dan dalam jangka waktu yang terbatas. Hal ini juga mengingatkan pada Yesus. Yesus adalah kepastian gaya hidup. Seperti dikatakan Yesus, setiap orang percaya harusnya meninggalkan kesenangan duniawi, menjauhkan diri dari kesenangan kedagingan, tidak hidup dengan orang-orang berdosa, berani menyatakan iman, memiliki kasih sayang yang murni, berpikiran rohani dan mengabdikan diri untuk pelayanan Tuhan dan menjadi teladan bagi sekitar manusia(Henry, 2005, p. 185).

Berdasarkan hal tersebut diketahui bahwa karena sumpahnya, seorang nazir memisahkan diri dari dunia dan hidup di bawah sumpahnya dengan cara memisahkan diri dari dunia.

\section{Gaya Hidup Pengkotbah Menurut Para Pakar}

Gaya hidup kerajaan menurut Crank adalah prinsip yang terbebas dari hutang. Seseorang yang terbebas dari hutang akan dapat lebih mengajarkan Injil. Prinsip dari gaya hidup tersebut adalah dengan memberi, kamu akan menerima. Terlebih setiap orang percaya memberi maka hidupnya akan semakin diberkati karena setiap orang yang memberi sedang bekerja sama dengan hukum yang mengikat secara rohani. Jika setiap orang percaya terbebas dari beban hutang maka terlebih harus memberi dan banyak benih yang ditanam maka akan membuat la- 
dangnya semakin diperluas (Crank, 1985, p. 5-6) Prinsip gaya hidup memberi ini, ditanamkan kepada para pengkotbah supaya dapat terbebas dari hutang. Prinsip-prinsip ini yang akan mebuat pengkotbah dapat menyikapi godaan yang terjadi akibat pengaruh hedon zaman milenial.

Gaya hidup orang percaya harus memiliki penjaminan di masa depan. Langkah-langkah yang dilakukan adalah merencanakan, displin, sabar, persepuluhan, setia, punya determinasi dan terakkhir tidak memiliki hutang. Langkah tersebut harus dikerjakan dengan sungguh-sungguh oleh orang percaya. Orang percaya harus mengandalkan Tuhan dalam setiap keputusan yang diambil berdasarkan hikmat Tuhan sehingga setan tidak bisa memberikan godaan terhadap manusia (Crank, 1985, p. 7-19). Gaya hidup seperti ini harus dimiliki oleh para pengkotbah. Langkah-langkah ini dapat dengan jelas dilakukan oleh para pengkotbah untuk dapat mengatasi setiap tantangan gaya hidup hedon pada zaman ini.

Motivasi dari gaya hidup yang terbebas dari hutang adalah bukan untuk kemewahan semata namun untuk mempersiapkan diri di masa-masa dingin atau masa-masa sukar. Hal ini seperti Yusuf yang menyimpan makanan untuk masa-masa sukar dan semut yang bekerja di musim panas (Crank, 1985, p. 41-43). Seorang pengkotbah harus memiliki motivasi tersebut untuk sebagai gaya hidup yang benar di sepanjang masa. Motivasi ini harus dihidupi dengan benar oleh para pengkotbah dengan mempersiapkan untuk masa-masa sukar.

Gaya hidup hamba Tuhan menurut Tandhiy adalah bahwa pada masa kini setiap orang yang sudah menyakini dan mengalami panggilan khusus dari Allah untuk melayani sepenuh waktu, dibuktikan dengan hasil atau buah pelayanannya, dan latar belakang teologi yang dimilikinya dan memiliki gaya hidup yang menunjukan profesionalisme pada panggilannya. Prinsipnya adalah warga jemaat memberikan upah yang layak atau hak yang sepatutnya oleh seorang hamba Tuhan akan tetapi tidak wajib bagi seorang hamba Tuhan tersebut untuk menuntut atau menerimanya (Tandhiy, 2017, p. 81-84). Prin- sip untuk tidak menuntut dari apa yang seharunya diberikan ini dimilii oleh setiap pengkotbah pada masa kini. Pengkotbah harus memiliki ketetapan yang jelas mengenai profesinya yang mengarah pada profesionalisme. Profesionalisme oleh karena panggilan ilahi yang harusnya menjadi hal yang utama bagi seorang pengkotbah.

Pengaruh Gaya hidup hedon seorang pengkotbah akan berdampak salah satunya adalah masalah hamba Tuhan atau rohaniwan yang menuntut gaji atau upah yang tinggi kepada jemaatnya, mungkin disebabkan oleh pemahaman mereka yang sempit akan profesi dan panggilan sebagai seorang hamba Tuhan sesungguhnya atau karena sikap inividualistis yang muncul karena pengaruh derasnya sekularisme dan materialisme. Masalah tersebut harus diatasi oleh seorang hamba Tuhan dengan memiliki langkah-langkah dalam membangun paradigmanya, yaitu: pertama, seorang hamba Tuhan harus memahami bahwa Allah adalah Tuan yang paling bertanggung jawab memenuhi dan menjamin kebutuhan hidup hamba-hamba-Nya. Kedua, seorang hamba Tuhan dalam hal ini patut menyesuaikan diri dengan kondisi kehidupan dari orang-orang yang dilayaninya. Ketiga, tahu bahwa tujuan akhir pelayanannya ialah mendapatkan kehidupan kekal di sorga bersama Yesus, Juruselamat (Tandhiy, 2017, p. 86-87). Motivasi yang benar dan harus dimiliki seoerang pengkotbah berkaitan dengan gaya hidupnya adalah mengetahui tujuan akhir pelayannnya bahwa pada akhrinya akan mendapatkan kehidupan kekal di sorga.

\section{Kecenderungan Gaya Hidup Global Pada Masa Kini}

Dekade ini kemajuan teknologi berkembang sangat pesat. Salah satu kemajuan yang pesat adalah dalam hal penyebaran informasi. Dulu media yang digunakan untuk menyebarkan informasi hanyalah sebatas media cetak saja, seperti koran dan poster. Kini penyebaran informasi semakin cepat karena dibantu dengan media televisi. Televisi bukan lagi barang mahal seperti masa dulu. Sekarang hampir di 
dalam setiap rumah, baik di kota maupun desa, terdapat televisi. Informasi yang disampaikan di televisi jauh terlihat lebih menarik daripada ketika hanya membaca koran atau melihat poster. Karena informasi dalam televisi ditampilkan dalam bentuk visual sekaligus audio (Gunawan, 2015 p.1). Hal tersebut berpengaruh terhadap perubahan gaya hidup yang terjadi pada masyarakat global. Imbas masyarakat global ini yang akan mempengaruhi juga kehidupan para pengkotbah pada masa kini

Pola gaya hidup mewah juga menjadi tren pada masyarakat pada masa kini. Bisnis barang mewah dapat dinikmati oleh berbagai kalangan masyarakat dan berkembang pesat di seluruh dunia (Ming, 2011, p ). Terdapat banyak produk mewah yang digemari secara internasional, seperti merk Gucci, Chanel, Louis Vuitton, Prada, dan Hermes. Hampir seluruh negara maju dan berkembang telah menikmakti fenomena " berburu" produk fashion mewah demi memenuhi gaya hidup konsumen (Annisa, 2014, p. 522). Hal ini berkaitan dengan gaya hidup global yang cendrung mengarah pada kebutuhan akan kebutuhan untuk memenuhi manfaat emosional (emotional life benefit). Gaya hidup global tersebut adalah gaya hidup yang mengarah pada hal-hal mewah. Gaya hidup mewah ini menunjukan pada gaya hidup untuk memenuhi kebutuhan emosinal yang dapat dikatan juga untuk memenuhi kesenagan. Gaya hidup ini maka akan disebut gaya hidup Hedon. Gaya hidup hedon ini berdampak pada kehidupan para pengkotbah pada masa kini.

Perubahan gaya hidup tidak lepas dari pengaruh media. Pengaruh kehidupan kebarat-baratan mulai bercampur pada kehidupan masyarakat. Memang tidak semua budaya dari barat tersebut yang tidak cocok dengan norma-norma orang timur, namun secara keseluruhan lebih cenderung memang tidak baik diterapkan dalam kehidupan sehari-hari. Pergeseran yang sangat signifikan terlihat pada masyarakat perkotaan. Dengan beragam suku dan ras telah bercampur pada masyarakat perkotaan maka gaya hidup tidak lagi terpatok pada kebiasaan satu daerah dan cenderung lebuh menganut gaya hidup bebas (Solihin, 2015, p. 42).

Masyarakat Indonesia sebagai masyarakat yang hidup di negara berkembang juga menggemari barang mewah baik merek luar negeri maupun dalam negeri (Annisa, 2014, P. 523). Untuk memotret fenomena perubahan gaya hidup masyarakat urban, hal tersebut dapat dilakukan dengan kecenderungan melihat perilaku mereka. Kalangan remaja dan dewasa memiliki kecenderungan untuk membelanjakan uangnya meskipun dalam posisi yang tidak sangat membutuhkan, salah satu penyebabnya karena adanya terpaan iklan. Berdasarkan deskripsi tersebut terdapat dampak global yaitu perubahan hidup yang mengarah pada hidup hedon pada masyarakat Indonesia terkhusus berimbas kepada gaya hidup seorang pengkotbah. Berdasarkan hal tersebut, gaya hidup pengkotbah pada masa kini terpapar akan adanya gaya hidup hedon akibat gaya hidup global yang juga turut berubah.

\section{Kecenderungan Gaya Hidup Pengkotbah Berdasarkan Data Lapangan Pendeta, Pelayan Fulltimer, dan Tim Pelayan}

Data lapangan diperoleh dengan melakukan wawancara dengan beberapa Pengkotbah, Pelayan fulltimer dan Tim Pelayan yang ada di Surakarta. Populasi pendeta di kota surakarta adalah 226 jiwa (Dukcapil, 2016, p. 39), belum ditambahkan untuk para fulltimer dan tim pelayan yang ikut melayani dalam pelayanan khotbah. Berdasarkan sebaran populasi tersebut dilakukan wawancara dengan mengambil sampel tersebut hingga didapatkan data yang cukup jenuh untuk di deskripsikan. Dari proses ini didapatkan 10 reponden dan dari data tersebut data dikatakan jenuh karena memiliki banyak kesamaan dalam jawaban-jawaban yang didapatkan. Pertanyaan di jawab dengan deskripsi sesuai dengan persepsi setiap responden.

Pertanyaan wawancara pertama bertujuan untuk mendapatkan gaya hidup global menurut para pengkotbah. Berdasarkan pertanyaan wawancara ini diharapkan didapatkan data gaya hidup global menu- 
rut pandangan para pengkotbah. Jawaban yang didapat dari pertanyaan ini diantarnya adalah: lebih mementingkan penampilan, hidup yang mengikuti perkembangan zaman, gaya hidup yang mengikuti ketertarikan karena iklan sehingga menginginkan hal-hal yang sebenarnya belum diperlukan. Pertanyaan wawancara kedua adalah untuk mengetahui gaya hidup para pengkotbah yang tidak tepat pada masa kini. Berdasarkan pertanyaan ini diharapkan ada data-data dari para responden mengenai gaya hidup pengkotbah yang tidak tepat dan dijelaskan dengan deskripsinya. Beberapa jawaban yang didapatkan diantaranya adalah: ingin terlihat sukses dengan menghalalkan segala cara, contohnya merebut jemaat lain, membuat kesalahan berdasarkan keinginannya sendiri, ingin terlihat mewah akhirnya korupsi, berkata kalau hidupnya pas-pasan tetapi memiliki mobil keluaran terbaru sedangkan mayoritas jemaat dalam kondisi keuangan cukup-menengah. Pertanyaan wawancara ketiga bertujuan untuk mendapatkan penyebab pengkotbah-pengkotbah yang memiliki gaya hidup tidak tepat pada masa kini. Berdasarkan pertanyaan wawancara ini diharapkan didapatkan data penyebab dan alasanya mengapa gaya hidup pengkotbah tidak tepat. Beberapa jawaban yang didapatkan diantarnya adalah: Karena tidak memiliki pengetahuan yang benar akan Firman Tuhan, karena sedang berproses dengan kedagingannya, karena ada keinginan tidak mau kalah saling sehingga menjadikan pengkotbah merupakan profesi yang harus diukur dengan pencapaian-pencapaian dan barang-barang mewah (Disarikan dari wawancara dengan responden Hamba Tuhan, Pelayan Full timer, dan Tim Pelayan di Surakarta). Pertanyaan wawancara keempat bertujuan untuk mengetahui pendapat-pendapat mengenai gaya hidup yang tepat bagi para pengkotbah masa kini. Berdasarkan pertanyaan wawancara ini diharapkan didapatkan hasil beberapa jawaban diantaranya adalah: Gaya hidup seperti Yesus, hidup sesuai Firman Tuhan yang dimampukan oleh Roh Kudus, hidup sederhana namun tidak kurang update, tidak keblabasan dalam penggunaan uang dan punya iman Tuhan cukupkan (Di- sarikan dari wawancara dengan responden Hamba Tuhan, Pelayan Full timer, dan Tim Pelayan di Surakarta).

\section{Analisis Persamaan Dan Perbedaan Nazir Dan Pengkotah Pada Masa Kini}

Perbandingan antara Nazir dan pengkotbah pada masa kini dibandingkan dengan studi persamaan dan perbedaannya adalah keduanya sama-sama mengkhususkan diri untuk pelayanan dan menjaga hidupnya sebagai teladan bagi orang lain. Keduanya juga merupakan pelayan Tuhan yang mengkhususkan diri untuk pekerjaan tersebut.

Perbedaannya adalah nazir merupakan orang yang memisahkan diri karena sumpah yang dibuat kepada Tuhan dan hidup untuk memenuhi nazarnya, sedangkan pengkotbah adalah orang yang dipanggil Tuhan untuk hidup sesuai panggilan-Nya dan melayani Tuhan dengan segenap hatinya. Seorang nazir sangat menjaga kekhususan hidupnya, sedangkan seorang pengkotbah pada masa kini lebih lentur mengenai gaya hidup yang dilakukan pada masa kini.

\section{Analisis Persamaan Dan Perbedaan Fokus Pelayanan Nazir Dan Pengkotbah Pada Masa Kini}

Fokus persamaan dari nazir dan pengkotbah adalah mereka sama-sama di sumpah untuk melakukan suatu perkerjaan khusus untuk Tuhan. Sumpah nazir membuat dirinya mengkhususkan diri untuk pelayan Tuhan. Pengkotbah adalah orang yang memberi diri untuk panggilan dalam pelayanan Tuhan terkhusus dalam pelayanan khotbah. Keduanya memiliki persamaan, yaitu mengkhususkan diri untuk pekerjaan pelayanan Tuhan dan diikat oleh sumpah kepada Tuhan.

Perbedaannya adalah pengkotbah melayani jemaat, sedangkan nazir juga melayani jemaat namun terikat oleh sumpahnya dalam jangka waktu tertentu. Sumpah tersebut boleh berkaitan untuk diri sendiri bagi seorang nazir sedangkan bagi seorang pengkotbah semuanya karena panggilan. 


\begin{tabular}{|c|c|}
\hline \multicolumn{2}{|l|}{$\begin{array}{l}\text { idup Nazir dan Gaya } \\
\text { ngkotbah menurut para } \\
\text { Ahli (Tesis) }\end{array}$} \\
\hline & $\begin{array}{l}\text { Prinsip hidup karena panggilan } \\
\text { Tuhan. } \\
\text { Memiliki prinsip gaya hidup yang } \\
\text { memberi dan profesionalitas seperti } \\
\text { Paulus }\end{array}$ \\
\hline & $\begin{array}{l}\text { Seorang nazir harus hidup saleh } \\
\text { menghindari setiap perbuatan yang } \\
\text { berpotensi pada dosa sehingga me- } \\
\text { miliki perataran dan disiplin hidup } \\
\text { yang ketat. }\end{array}$ \\
\hline
\end{tabular}

Gaya hidup pengkotbah yang didasari Firman Tuhan dan seperti Yesus, gaya hidup pengkotbah memiliki langkah-langkah merencanakan, displin, sabar, persepuluhan, setia, punya determinasi dan terakkhir tidak memiliki hutang.

Gaya hidup pengkotbah yang pertama, seorang pengkotbah harus memahami bahwa Allah adalah Tuan yang paling bertanggungjawab memenuhi dan menjamin kebutuhan hidup hamba-hamba-Nya. Kedua, seorang pengkotbah dalam hal ini patut menyesuaikan diri dengan kondisi kehidupan dari orangorang yang dilayaninya. Ketiga, tahu bahwa tujuan akhir pelayanannya ialah mendapatkan kehidupan kekal di sorga bersama Yesus, Juruselamat.

Motivasi gaya hidup seorang nazir karena menjaga sumpahnya dan dapat menjadi teladan bagi orang lain.

Motivasi hamba Tuhan adalah hidup seperti Yesus dengan pertolongan Roh Kudus.

Gaya hidup pengkotbah yang terbebas dari hutang bukan untuk kemewahan akan tetapi untuk hidup pada masa-masa yang sukar.

Motivasi profesionalisme gaya hidup pengkotbah adalah untuk

\section{Gaya hidup Pengkotbah pada masa kini (Antitesis) \\ Prinsip gaya hidup yang terpe- ngaruh terpaan media dan per- kembangan zaman sehingga me- miliki prinsip hidup hedon yaitu untuk mencari segala seuatu yang menyenangkan}

Gaya hidup yang memiliki langkah-langkah atau pola kemewahan. Kecendrungannya adalah gaya hidup konsumtif yaitu membeli apa yang tidak diperlukan. Kecendrungan hidup menyenangkan dengan cara memiliki barang-barang yang seharusnya tidak perlu seperti barang-barang mewah.
Menjaga prinsip hidup secara profesional yang menghidupi panggilan Tuhan secara khusus, seperti sumpah yang dilakukan oleh seorang nazir dan utamanya memiliki konsep hidup untuk memberi.

Langkah yang diutamakan adalah: pertama, mengerti dan memahami panggilan Tuhan akan pelayanannya. Kedua, di tengah gaya hidup global yang menuntut kemewahan patut menyesuaikan diri dengan kesederhanaan, memiliki disiplin hidup yang ketat, akan tetapi tetap update untuk memberi jawaban pada masayarakat global yang memiliki gaya hidup mewah. Ketiga, memiliki jaminan iman bahwa Yesus adalah pemelihara hidupnya.
Motivasi utama adalah memenuhi kebutuhan emosionalnya dibandingkan memenuhi kebutuhan fungsionalnya. Berdasarkan hal tersebut maka pemenuhan akan motivasi dilakukan dengan memiliki pola hidup mewah dan cenderung hedong untuk mengejar kesenangan pribadi.
Motivasi pengkotbah adalah kembali pada panggilannya dan bukan seturut dengan dunia untuk memenangkan banyak jiwa. Profesional akan panggilannya tetapi tetap menjaga diri dan memisahkan diri dari perkembangan tuntutan kehidupan mewah secara global. 
menghidupi panggilan Tuhan, menerima setiap pemberian yang diperuntukkan namun tidak memberikan tuntutan terhadap gaji/insentif.

Tabel 1. Analisis Model Gaya Hidup Pengkotbah Pada Generasi Milenial

\section{Model Gaya Hidup Nazir Sebagai Refleksi Gaya Hidup Hedon Pengkotbah Pada Zaman Milenial}

Berdasarkan analisis di atas di dapatkan model gaya hidup Nazir sebagai refleksi gaya hidup hedon pengkotbah pada zaman milenial. Hal tersebut di deskripsikan dalam tiga hal yaitu: prinsip, langkah-langkah, dan motivasi dalam kaitannya dengan gaya hidup pengkotbah pada zaman milenial.

\section{Pertama, prinsip gaya hidup nazir sebagai refleksi} gaya hidup pengkotbah pada zaman milenial

Pada prinsipnya pengkotbah pada zaman milenial ini harus memiliki sikap profesional dalam panggilannya seperti seorang nazir yang menjaga sumpahnya dengan konsep memberi. Pengkotbah hidup dalam perkembangan zaman, namun tetap memberi dalam setiap kelimpahan yang dimiliki dan tidak hidup mengikuti trend global yang menuntut dalam hal kemewahan. pengkotbah menjaga panggilannya seperti seorang nazir yang menjaga sumpahnya sebagai kebanggaannya. Panggilan tersebut yang menjadi gaya hidup utama seorang pengkotbah dan tidak larut dengan kehidupan dunia ini.

Prinsip profesionalitas pengkotbah tidak mengedepankan yang diterima, namun mengedepankan pemberian. Pengkotbah hidup dalam planning ke depan untuk menghadapi masa-masa sukar baik dirinya, keluarganya maupun jemaat. Kehidupan yang mengerti tentang perkembangan zaman namun tidak larut di dalam-Nya. Pengkotbah tetap hidup dalam panggilannya dan dalam habbit atau kebiasasaan untuk memberi. Pengkotbah yang terlebih memberi dan mempertimbangkan masa-masa sukar akan menghindarkan dari hidup kemewahan dan tidak larut dalam kesenangan duniawi seperti seorang nazir yang sedang mengkhususkan dirinya.
Kedua, langkah-langkah gaya hidup nazir sebagai refleksi gaya hidup pengkotbah pada zaman milenial.

Perkembangan zaman masa kini atau dikenal dengan zaman milenial menuntut setiap orang untuk hidup hedon dan mengedepankan konsumerisme. Masyarakat lebih mementingkan nilai emosional bukan nilai manfaat ketika membeli suatu kebutuhan hidupnya. Barang-barang bermerek menjadi pilihan sehingga utamanya adalah kehidupan mewah. Langkahlangkah pengkotbah dalam hidup dalam dunia tersebut adalah: pertama, mengerti prinsip utama pengkotbah, yaitu mengerti panggilan-Nya dalam kehidupan. Seorang pengkotbah harus menghidupi panggilanNya dan menjaga kekhususan panggilannya. Seperti seorang nazir menjaga sumpahnya, demikian juga seorang pengkotbah menjaga panggilannya.

Kedua, di tengah gaya hidup global yang menuntut kemewahan patut menyesuaikan diri dengan dengan kesederhanaan, memiliki disiplin hidup yang ketat, akan tetapi tetap update untuk memberi jawaban pada masayarakat global yang memiliki gaya hidup mewah. Paradigma hidup sederhana bukan hidup yang ketinggalan zaman harus dimengerti dan dihidupi oleh setiap pengkorbah.

Pengkotbah dituntut untuk menyesuaikan diri dengan perubahan zaman yang menawarkan kemewahan namun dengan ketat mendisiplin diri untuk tidak larut dalam gaya hidup tersebut. Pengkotbah hidup untuk berani menolak tantangan global yaitu gaya hidup yang bertujuan akhir pada kemewahan, konsumerisme, dan hedonisme. Edukasi juga harus diberikan kepada warga jemaat dalam gaya hidup yang demikian sehingga tidak menghakimi pengkotbah yang hidup dalam kesederhanaan. Edukasi bahwa berkat bukan hanya ditinjau dari material dan kemewahan. Melalui gaya hidup ini pengkotbah 
menjadi teladan gaya hidup bagi seluruh orang percaya.

Ketiga, mengerti tujuan akhir dari pelayanan ini adalah kehidupan kekal di surga. Seorang pengktobah mengarahkan diri untuk mengerti tujuan akhir ini dan membawa tugas panggilan ini agar setiap jemaat atau orang percaya juga memiliki kepastian keselamatan.

Ketiga, motivasi gaya hidup nazir sebagai refleksi gaya hidup pengkotbah pada zaman milenial

Motivasi gaya hidup seorang pengkotbah yang benar adalah kembali kepada panggilannya bukan turut mengikuti kesenangan yang bersifat duniawi dengan tujuan untuk memenangkan jiwa tetapi tetap pada profesionalitas seorang pengkotbah yang taat akan panggilannya dengan cara memisahkan diri dari kehidupan duniawi. Melalui motivasi ini diharapkan kemurnian tugas panggilan seorang pengkotbah akan tetap terjaga seperti seorang nazir yang menjalankan nazarnya. Motivasi gaya hidup yang berdasarkan panggilan ilahi harus dimiliki oleh setiap pengkotbah dalam setiap aspek pelayanan mereka.

\section{KESIMPULAN}

Berdasarkan hal di atas dapat disimpulkan bahwa melalui penelitian ini didapatkan model gaya

\section{DAFTAR RUJUKAN}

Annisa, Renny. 2014. "Alasan Gaya Hidup Konsumen dalam Mengkonsumsi Kebaya Sebagai Barang Mewah", Jurnal Aplikasi Manajemen. Vol 12, No 3.

Bernatta, Ratu Aulia Rahmani, 2017.“ Gaya Hidup Hedonis di Kalangan Remaja (Studi Pada Komunitas Mobil LSC 81 Club), Skripsi, Lampung: Fakultas Ilmu Sosial dan Ilmu Politik Universitas Lampung.

Dukcapil, 2016. Profil Perkembangan Kependudukan Kota Surakarta Tahun 2016. (Surakarta: Pemerintah Kota Surakarta)

Crank, David. 1985. Goodly Finances and the Bible Way to Pay off Your Home, USA : David Crank Publication. hidup nazir sebagai refleksi gaya hidup pengkotbah pada zaman milenial. Model gaya hidup tersebut dijelaskan dalam tiga hal, yaitu: Pertama, prinsipnya adalah hidup profesional sebagai seorang pengkotbah yang menghidupi panggilannya dan memiliki habbits memberi. Kedua, memiliki langkah-langkah gaya pengkotbah Tuhan yaitu: pertama mengerti dan memahami panggilan Tuhan akan pelayanannya, kedua di tengah gaya hidup global yang menuntut kemewahan patut menyesuaikan diri dengan dengan kesederhanaan, memiliki disiplin hidup yang ketat akan tetapi tetap update untuk memberi jawaban pada masayarakat global yang memiliki gaya hidup mewah. Ketiga, memiliki jaminan iman bahwa Yesus adalah pemelihara hidupnya. Ketiga, memiliki motivasi kembali kepada panggilannya bukan turut mengikuti kesenangan yang bersifat duniawi dengan tujuan untuk memenangkan jiwa tetapi tetap pada profesionalitas seorang pengkotbah yang taat akan panggilannya dengan cara memisahkan diri dari kehidupan duniawi.

Saran dari penelitian ini adalah perlu dilakukan penelitian lanjutan secara kuantitatif berapa efektifitas presentase model ini terhadap perubahan gaya hidup pengkotbah pada zaman milenial.

Fleming, Don. 2005. Bridge Way Bible Commentary. Brisbane: Bridge Way Publication.

Goenawan, Felicia. 2008. "Nilai dan Gaya Hidup Masyarakat di Dalam Media." Jurnal Ilmiah Scriptura, Vol 2, No 2.

Gunawan, Ivan Kristianto et al. 2015. "Representasi Gaya Hidup Mewah dalam Iklan Televisi Es Krim Magnum Versi "Magnum Classic", Jurnal DKV Adiwarna, Vol 1.

Gray, James M. 1999. The concice Bible Commentary: A Clear and Understandable Overview of the Old and New Testaments Complete in one Volume. California: Hendricson Pub.

Haryono, Timotius \& Daniel Fajar Panuntun, 2019, "Andil Pemuridan Kontekstual Yesus Kepa- 
da Petrus, Yakobus, dan Yohanes Terhadap Keterbukaan Konseling Mahasiswa pada Masa Kini”, Jurnal gamaliel: Teologi Praktika. Vol 1, No 1.

Henry, Matthew. 2005. Matthew Henry's Concise Commentary on The Bible, Grand Rapids, MI: Christian Classics Ethereal Library.

Jamieson, Robert et al. 2009. Commentary Critical and Explanatory on the Whole Bible, Grand Rapid, MI: Christian Classics Ethereal Library.

Lumintang, Stevri Indra dan Danik Astuti Lumintang.2016. Theologia penelitian dan Penelitian Theologis science-ascience serta metodologinya, Jakarta: Geneva Insani Indonesia.

Miles, M. B. \& Huberman, A. M. 1984. Qualitative Data Analysis: A Sourcebook of New Methods. California. SAGE publications Inc.

Ming, W.S. 2011. "Consumption of Luxury Fashion Brands: The Motives of Generation Y Consumers in China." Thesis. Auckland University of Technology Masterof Business.

Nugroho, Fibry Jati. 2019. Gereja dan Kemiskinan: Diskursus Peran Gereja Di Tengah Kemiskinan. Evangelikal: Jurnal Teologi Injili dan Pembinaan Warga Jemaat. Vol 3. No 1.

Nurdin. 2005. Guru Profesional \& Implementasi Kurikulum. Jakarta: Quantum Teaching.
Perpustakaan Online Menara Pengawal, Nazir, Diakses darihttps://wol.jw.org/id/wol/d/r25/lpin/1200003191. Pada 14 Ferbruari 2019. Pukul 08.58.

Ronda, Daniel. 2019. "Kepemimpinan Kristin di Era Disrupsi Teknologi." Evangelikal: Jurnal Teologi Injili dan Pembinaan Warga Jemaat, Vol 3. No 1.

Sitanggang, Murni Hermawaty, dan Juantini. 2019. "Citra Diri Menurut Kejadian 1 : 26-27 dan Aplikasinya Bagi Pengurus Pemuda Remaja GPdI Hebron Malang." Evangelikal: Jurnal Teologi Injili dan Pembinaan Warga Jemaat, Vol 3. No 1.

Solihin, Olih. 2015. "Terpaan Iklan Mendorong Gaya Hidup konsumftif Masyakarat Urban", Jurnal Ilmu Politik dan komunikasi,.

Sugiyono. 2015. Metode Penelitian dan Pengembangan (Research and Development). Bandung : Alfabeta.

Tanhidy, Jamin. 2017. "Profesionalisme Hamba Tuhan", Melaksanakan Amanat Agung di Abad 21: Bunga Rampai. Semarang: Sekolah Tinggi Teologi Simpson.

Wright, R. 2006. Consumer Behaviour. Hampshire: Cengage learning EMA. 